\title{
Enterprise competitiveness as an informative characteristic of leadership
}

\author{
Marina Borovitskaya \\ Financial University under the Government of the Russian Federation \\ Leningradsky Prospekt, 49, 125993, Moscow \\ Russian Federation \\ e-mail: geht066@mail.ru \\ Anna Sherstobitova \\ Department of magistracy (economic and management programs) \\ Togliatti State University \\ Belorusskaya St., 14, 445020 Togliatti \\ Russian Federation \\ e-mail: prof.glv@yandex.ru \\ Olga Shnayder \\ Financial University under the Government of the Russian Federation \\ Leningradsky Prospekt, 49, 125993 Moscow \\ Russian Federation \\ e-mail: shnaider-o@mail.ru
}

\begin{abstract}
Russian enterprises operate in the market terms which dictate a constant search for strategic developments aimed at ensuring at the leading positions in the sector, industry and competitiveness increase. Success and leadership in a competitive economy are possible in the case of an objective studying and assessment of their own potential and the competitors' potential, their goals and strategies, identifying the strengths and weaknesses of competitors. Due to this in the long term it is possible to concentrate on the directions in which the competitor much weaker and to expand one's own advantages and opportunities.

Any enterprise cannot function without competitors' activity because all enterprises and their competitors are the links of one chain - economy. The indispensable factor defining the right for existence of any organization is the competition that allows to point out from a large number of the organizations - the leaders who are capable to make really qualitative and modern goods and services demanded by the population.

With regard to the above, adoption of reasonable decisions in favor of competitiveness increase of separately taken organization has to be based on careful studying of features and characteristics of competitors.
\end{abstract}

\section{Introduction}

Nowadays, the competition and the competitiveness are the major concepts for Russian economy. It is considered that the competition is a driving force of the relations of market figures and evolution of their partnership that is one of the most creative forces of economic system (Levitt 1976; Grant 1996; Fatkhutdinov 2000; or Porter 2005). Those enterprises which are capable to take out the competition are most successful participants of market relationship, the most competitive ones (Orlova et al. 2018). The leading positions of the enterprise directly depend on ability to provide such goods and services which precisely meet the customers' needs and the market in general.

The leadership, success, as well as ruling out possible competitors are ultimate goals of each organization, this victory has to be a natural result of invariable efforts. Therefore, enterprise management constantly and continuously looks for new tools and numerous levers which will be able to increase competitiveness in competitiveness for achieving the leading positions on the market (Ryckman 1985; Itami and Roehl 1987; Henman 2009; or Oláh et al. 2017; or Batkovskiy et al. 2018).

The competitiveness as a multiple-valued concept includes not only the price and qualitative parameters of industrial goods but also depends on the created control system of financial flows, at the level of management, investment and innovative components of its policy (Narkunienè and Ulbinaite 2018). Moreover, the level of the competition which the enterprise is occurred by other market participants, an environment which develops in various markets, financial stability, hardware, level of innovation implements, motivational policy and staff qualification, etc. influence on the competitiveness (Kotler 2015; Krayneva et al. 2017; or Lazányi et al. 2017). 
The administrative staff should competently manage the enterprise competitiveness in order to increase its level, namely: i) to systematically analyze the markets where they work; ii) to reveal advantages and disadvantages of competitors and to qualitatively carry out the assessment of the competitiveness level; iii) to use the advantages, opportunities; and iv) to exclude/fight against the disadvantages and threats.

\section{Competitiveness as management tool}

The competitiveness is the most difficult concept with various meanings. Such aspects of activity as goods or service and its main/distinctive properties and qualities; production technology; relevance; availability for the customer are included in this concept by any organization (Būmane 2018). There are several definitions of competitiveness and we provide some selected ones based on the short and comprehensive literature review in the table that follows (Table 1).

Table 1. Characteristic of the Concepts "Enterprise Competitiveness" and "Product Competitiveness"

\begin{tabular}{|c|c|}
\hline Author & Definition \\
\hline $\begin{array}{l}\text { "European } \\
\text { Management Forum" } \\
\text { (Switzerland) } \\
(2004)\end{array}$ & $\begin{array}{l}\text { The firm competitiveness is a real and potential ability of the companies and also the } \\
\text { opportunities which are available for them for this purpose to project, produce and } \\
\text { sell the goods which according to the price and not price characteristics in a complex } \\
\text { are more attractive for consumers, than the goods of competitors }\end{array}$ \\
\hline $\begin{array}{l}\text { Toyohiro Kono } \\
\text { (Japan) } \\
(1987)\end{array}$ & $\begin{array}{l}\text { Enterprise competitiveness as a set of the following characteristics: } \\
\text { 1) market share taken by the enterprise; } \\
\text { 2) enterprise ability for production, sale and development; } \\
\text { 3) top-management ability for goal achievement. }\end{array}$ \\
\hline $\begin{array}{l}\text { Fatkhutdinov } \\
\text { (Russia) } \\
(2000) \\
\end{array}$ & $\begin{array}{l}\text { Competitiveness ability - is the property of an object, characterized by the degree of } \\
\text { its real or potential meeting the competitive requirements in comparison with the } \\
\text { similar objects presented at this market. }\end{array}$ \\
\hline $\begin{array}{l}\text { Bubnov } \\
\text { (Russia) } \\
(2002)\end{array}$ & $\begin{array}{l}\text { Competitiveness - is the characteristic of a product that reflects its difference from } \\
\text { the competitor's product on a degree of compliance within a specific social need and } \\
\text { on costs of meeting them. }\end{array}$ \\
\hline $\begin{array}{l}\text { Eleneva } \\
\text { (Russia) } \\
(2001)\end{array}$ & $\begin{array}{l}\text { Competitiveness - is a set of the production properties meeting the consumer } \\
\text { requirements for quality and the standard-organizational and economic consumer } \\
\text { requirements for acquisition and operation of this production as well. }\end{array}$ \\
\hline $\begin{array}{l}\text { Ermolov } \\
\text { (Russia) } \\
(2001)\end{array}$ & $\begin{array}{l}\text { Enterprise Competitiveness - the relative characteristic reflecting difference of } \\
\text { development of the producer from the rival producer both on the degree of meeting } \\
\text { specific social need with the goods or services and on the efficiency of production } \\
\text { activity. }\end{array}$ \\
\hline
\end{tabular}

Source: Mironov (2004)

One can see that Ermolov (2001), Bubnov (2002) and Eleneva (2001) interpreted the concept of enterprise competitiveness within the context of the concept of product competitiveness. According to them enterprise competitiveness and product competitiveness are correlated to each other as a part and the whole, i.e. the enterprise competitiveness is manifested through the product competitiveness as reports the certain consumer properties to it. It is possible to present the characteristic of enterprise competitiveness as possible quality of the enterprise which consists of:

1. The enterprise ability to realistically assess the expectations of the target audience of customers, to monitor the trends in consumer behavior, which suggests that the company should be able to impartially timely and accurately assess the demand of buyers at the definite moment of time and to make forecasts of the dynamics in the future.

2. The ability to organize the production, the results of which meet the expectations of a group of consumers which the manufacturer focuses on. Speaking about the results, it isn't meant only the consumer quality of the product or service, but also its quality in terms of marketing assessment: the price, warranty, warranty service after the sale, etc.

3. The ability to effectively implement current marketing policies.

4. The ability to find and create the conditions to reduce the costs on supplement of productivity factors - raw materials, capital, the power per unit of sold goods, labor.

5. The ability to create and maintain the technological effectiveness of production over the other participants of the industry structure, in this regard, it is necessary to update the technologies that are used for production, marketing and management.

6. The ability to plan, organize and implement an effective strategy in all areas of production and marketing policy based on the innovation. 
7. The ability to create and develop a high human resource, both at the level of performance and at the managerial level (World Economic Forum 2017).

All of the above characteristics of competitiveness increase the potential of the enterprise and reduce its unit costs in the financial, raw materials and other markets which directly affects the price of goods and profits that the company receives. Hence, the relationship between the enterprise's ability to compete and the market competition is characterized as a ratio of "enterprise potential and its use".

At the same time the implementation of 1-3 points contributes to the increase in the enterprise profitability at the expense of a much better understanding of consumer needs and the ability to satisfy them than competitors' ones. The fourth property is to assist in reducing unit costs for the production of goods, and all together properties 1-4 contribute to the current economic efficiency of the enterprise and characterize the level of adaptation of its behavior, the ability to adapt to the requirements of the environment at the moment.

Properties 1, 5 and 6 allow competently and accurately to carry out planning and implement ideas in the technological, commodity and marketing aspects, which are the basis for the competitiveness of products and services of the enterprise in the long term.

The company's potential in the field of innovation is created from these properties which also allow to identify the trends and to predict the state of the environment in future periods, based on the conditions for strategic planning of successful adaptation to them.

\section{The effect of product competitiveness on the leadership and enterprise success}

The parameters of the economy are correlated with the consumer's spending on the purchased goods. These indicators include the following: the price of the goods, transportation costs and storage, installation and repairing, as well as all current costs in the process of using. Market saturation, demand and supply are the most important factors which affect the enterprise ability to compete.

The consumer organizations, the ultimate consumer assesses the competitiveness of an economic entity. Russian domestic consumer determines the competitiveness of goods or services by "voting" with Russian ruble. The competitiveness criterion is the qualitative and quantitative characteristics used as the basis for assessing its competitive advantages. The integral quality index as the proportion of the total useful effect from the product use as intended and the total cost of the creation and operation of products is used as the main indicator of product competitiveness.

The product ability to compete is the main component of the enterprise competitiveness. The product competitiveness is expressed in the ability to meet the needs of the competitive market, the requirements of consumers in comparison with other similar products which are presented in the market. It is determined by the quality properties of the product, its level of technical characteristics, consumer properties and the product prices determined by the sellers. In addition, competitiveness depends on such factors as fashion, advertising, sales and after-sales service, market conditions, and demand stability.

Therefore, the competitive ability of the product is a set of all its advantages in the market which contributes to the successful sale and positive competition. This point of view is determined by the system of consumer, technical and economic indicators: social, functional, aesthetic and other useful properties, technical characteristics of the product, the purchase price and consumption costs. Comparing these indicators with indicators of the product-competitor it is possible to make an assessment on criteria of prospect and normativity.

To manage the product competitiveness is possible and necessary as it helps to ensure the enterprise competitiveness. Planning of competitiveness indicators is carried out at the stage when the product itself is designed. The task for marketing specialists in this activity is to find the indicators of quality, after-sales service, cost which determine the product competitiveness ensuring its success.

The ratio of the quality and price indicators to the service is the main feature to ensure the product competitiveness in the market. Surely, the reasons for success or failure can be the effect of such factors as advertising, brand prestige, etc. but the competitiveness is laid at the stage of project creation and production, therefore, is limited to the influence of marketing in the course of sales activities.

\section{Conclusions}

The future operation of a company depends on how much demand products will be produced by this or that company, that is why modern enterprise which seeks to take and maintain a leading position in the market should constantly pay special attention to the indicators of its competitiveness. In order to increase the level of organization competitiveness it is necessary to raise the competitiveness potential of the departments to the level of world leading manufacturers in the market of this industry. This indicator characterizes the potential of the company's successful work in the future. Business success at present does not guarantee a bright future. In addition, it is important to ensure the product competitiveness. As you know the product competitiveness is the 
property of the production object at a certain time, to surpass the quality and price characteristics of the productcompetitors without loss for the manufacturer.

Ensuring the competitiveness is a significant task, the solution of which is interconnected with the improvement of production, sales and maintenance of products that is with the implementation of targeted activities for the becoming, formation and maintenance of the level that is required for highly competitive ability in all periods of the life cycle of the enterprise and products.

The ability of the enterprise to resist the competition in the market depends on such factors as the level of sales, reputation, high motivation of the team, the ability of management to establish the necessary contacts in the team and the business environment. High competitiveness is one of the inseparable components of the enterprise success.

The companies which managed to take the top positions in the financial and economic market have a huge authority and can have a serious impact on their competitors, forcing them to take any rules of the market game. The enterprises which are unable to withstand the pressure of competitors and do not possess effective development of technologies, as a rule, lose their position for benefit of the competitors during "races" for profit. Therefore, the higher the company's competitiveness indicators are, the more likely it is to achieve a leading position.

\section{References}

Batkovskiy AM, Kalachikhin PA, Semenova EG, Telnov YF, Fomina AV, Balashov VM (2018) Configuration of enterprise networks. Enterpreneurship and Sustainability Issues 6(1):311-328. doi: 10.9770/jesi.2018.6.1(19)

Bubnov Y, The Methodology of competitiveness regulation the industrial enterprise, 1st edn. (Samara: Publishing house Samar. state Econ. Academy of Sciences, 2002), 276 p.

Būmane I (2018) The methodology of the statement of comprehensive income and its impact on profitability: the case of Latvia. Entrepreneurship and Sustainability Issues 6(1):77-86. doi: 10.9770/jesi.2018.6.1(6)

Eleneva Y (2001) Competitiveness of the enterprise: approaches to providing, criteria, methods of assessment. Marketing in Russia and abroad 6: 29-35.

Ermolov M, Competitiveness of enterprises, 1st edn. (SPb.: Business press, 2001), $271 \mathrm{p}$.

Fatkhutdinov R, Organization of production, 1st edn. (Moscow: INFRA-M, 2000), 250 p.

Grant R (1996) Prospering in dynamically-competitive environments: Organizational capability as knowledge integration. Organization Science 7(4):375-387. doi:10.1287/orsc.7.4.375

Henman L (2009) Leadership: Theories and Controversies. http://www.henmanperformancegroup.com/articles/Leadership-Theories Accessed 15 Oct 2017

Itami H, Roehl T, Mobilizing Invisible Assets, 1st edn. (Harvard University Press, 1987), 200 p.

Kotler F, Basics of marketing, 5th edn. (Moscow: Williams Publ. 2015), 598 p.

Krayneva R, Bugaev A, Zhuravleva T, Vojtovič S (2017) Management and promotion of economic innovation potential. Journal of International Studies 10(1):146-158. doi: 10.14254/2071-8330.2017/10-1/10

Lazányi K, Čepel M, Bilan S (2017) Comparison of Trust and Social Relations among Students in Russian and Hungarian Higher Education. Economics and Sociology 10(4):162-174. doi:10.14254/2071-789X.2017/10-4/13

Levitt T (1976). The management and the 'Post-Industrial' Society. The Public Interest, 44: 69-103.

Mironov MG, Your competitiveness, 1st edn. (Moscow: Alpha Press Publ. 2004), 159 p.

Narkunienė J, Ulbinaitė A (2018) Comparative analysis of company performance evaluation methods. Entrepreneurship and Sustainability Issues 6(1):125-138. doi:10.9770/jesi.2018.6.1(10)

Oláh J, Bai A, Karmazin Gy, Balogh P, Popp J (2017) The Role Played by Trust and Its Effect on the Competiveness of Logistics Service Providers in Hungary. Sustainability 9(12):2303. doi:10.3390/su9122303

Orlova L, Gagarinskaya G, Gorbunova Y, Kalmykova O (2018) Start-ups in the field of social and economic development of the region: a cognitive model. Entrepreneurship and Sustainability Issues 5(4):795-811. doi:10.9770/jesi.2018.5.4(7) 
Porter M, Competitive advantage: how to achieve high results and ensure its sustainability, 1st edn. (Moscow: Alpina Publisher, 2005), 454 p.

Ryckman R, Theories of personality, 1st edn. (Monterey, CA: Brooks / Cole Publishing Co, 1985), 514 p.

Toyohiro K, Strategy and structure of Japanese enterprises, 1st edn. (Moscow: Progress, 1987), 384 p.

World Economic Forum (2017) A Partner in Shaping History. The First 40 Years http://www3.weforum.org/docs/WEF_First40Years_Book_2010.pdf Accessed 15 Jun 2017 